\title{
Anti/Postwork Feminist Politics and a Case for Basic Income
}

\author{
Kathi Weeks
}

Duke University, Durham, NC, USA, kweeks@duke.edu

Abstract: This article presents a defence of the demand for a guaranteed basic income against recent Left critiques. Drawing on a series of lessons from the 1970s-era demand for Wages for Housework, I argue in favour of a demand for a liveable and universal basic income as a coalitional, antiproductivist, antifamilial reform that can help to alleviate some of the ways that the current wage-and-family system miscounts our economic contributions and fails as a system of income distribution.

Keywords: basic income, domestic labour, Wages for Housework, Marxist feminism, antiwork, postwork, antiproductivism, antifamilialism, autonomy.

Acknowledgements: I am grateful to participants at the following venues for lively, challenging, and comradely debate about many of these ideas: Cornell Society for the Humanities Fellows Seminar in 2020, the 2019 conference sponsored by CHASE and Autonomy on Challenging the Work Society: An Interdisciplinary Summit, and the Future of Work panel at the 2018 NWSA meeting. Thanks also to Katie Cruz and Cameron Thibos for help in formulating some of these arguments.

\section{Introduction}

Once treated as either a dangerously delusional fantasy or, occasionally, a naïvely distracting caprice, the demand for a guaranteed basic income in the US is now being debated across multiple forums, from mainstream and alternative media sites to more academic venues. I would, however, hesitate to describe all of these critiques as equally substantive; some of the pieces, committed as they are to refuting the demand and discrediting its politics, rely on straw figures and, due in part to the conventions of non-academic publishing, employ minimal citation practices. ${ }^{1}$ The new interest that the politics of basic income has received of late, among its various supporters and detractors, inspired the following revisiting and reaffirmation of my commitment to the demand as part of a feminist antiwork and postwork political practice in the US, but with relevance beyond its borders.

Let me start by specifying something about both the demand I am going to argue in favour of and the case I am going to develop. ${ }^{2}$ There are many different proposals that travel under the label of a basic income. The version that I want to defend is for a minimal liveable income regularly remitted as a social wage, paid unconditionally to residents regardless of citizenship status, regardless of family or household membership, and regardless of past, present, or future employment status. Waged work would not be replaced by such a social wage, but the link between work and income would

${ }^{1}$ For other helpful efforts to sort through some of the critiques of the basic income demand see Frase (2018) and Stronge (2017).

2 I have developed defences of the demand for basic income in previous publications. See Weeks and Cruz (2016), Weeks and Thibos (2019), and Weeks (2011). 
be relaxed, allowing more room for different ways of engaging in, or possibly opting out of, waged labour. Similarly, the family would not necessarily wither away, but by mitigating the connection between the distribution of wages and family membership, a basic income could help to support a wider variety of household forms and enable new relations of care and intimacy to develop. Such a guaranteed income would enable waged work, marriage contracts, and childrearing to be somewhat more a matter of choice than they are at present, where all three are subjected to a strict and miserly economic calculus.

As for the case I build to support the demand, it is deeply informed by the tradition of Marxist feminist thought through which I first became interested in basic income and which continues to inform my understanding of its political possibilities and limitations. This tradition comprises the 1970s Wages for Housework literature as presented in a selection of writings by authors including Mariarosa Dalla Costa, Selma James, Silvia Federici, and Nicole Cox. Other defences of basic income draw upon other intellectual traditions to develop different formulations of and rationales for various iterations of the demand. Liberal, libertarian, neoliberal, socialist, and techno-futurist versions of the demand, among others, have been advanced; some of the more confused and misleading critiques of basic income elide such differences or conflate some of the less congenial versions as tactics to elicit the reader's negative response. The specific reasons why Wages for Housework of the 1970s is important to my conception of the politics of basic income will be spelled out in more detail as we move through the argument. For now, I will just note that it offers some increasingly relevant insights into late capitalist political economies and their changing landscapes of work; perceptive analyses of the functions of the wage system within a broad accounting of capitalist production and reproduction; a more capacious and formidable conception of who might be included in the 'working class' of Left politics; and perhaps most important, an inspired analysis of the political practice of formulating and advancing demands. My argument is divided into a series of discussions, each drawn from a specific lesson gleaned from readings of the Wages for Housework literature.

\section{Lesson \# 1: The Wage System Miscounts Participation in Capitalist Valorisation}

The first lesson relevant to discussions of the politics of basic income in the US speaks to the question of how to understand the wage system in a more expansive way that allows us to recognise the full range of its failures as a system of both productive reward and income allocation. I will start with the original analyses from the 1970s and then consider how they might be adapted to the present moment. The Wages for Housework theorists insisted that we need a more capacious conception of the economy and of what counts as an economic relation in order to account for all of the productive effort involved in capitalist valorisation and how it shapes our social relations. "Marx clarified long ago", Cox and Federici point out, "that the wage hides all the unpaid work that goes into profit". "But," they continue, "measuring work by the wage also hides the extent to which all our social relations have been subordinated to the relations of production" $(1976,9)$. As an alternative to what was then the privileged site of Marxist analysis, namely the factory, together with other autonomist Marxists they examined two of the key components of that more expansive conception of the economy that they called the social factory: waged work and the family. The wage system, as the main instrument of income distribution, relies on a second institution, the privatised family, which serves as the primary locus for the reproductive labour, performed disproportionally by women, that is necessary to reproduce workers on a daily and generational basis. So the wage-and-family work system encompasses the systems of 
production centred on waged work and of reproduction conducted within the site of the household and held together by the institution of the family, which remains the means by which many of us are recruited into these unwaged and gendered relations of reproduction and governed once we are there. By examining unwaged domestic-based caring work, consumption work, housework, and community-creation work as forms of reproductive labour upon which productive labour, more narrowly conceived, depends, and by viewing the household as a workplace and the family as a managerial regime that organises, distributes, and manages that site, they expanded not only what counts as the economy but who must be considered as part of the working class.

To make the link between the demand for basic income and this model of the social factory, which extends the sites and relations of capitalist production (the 'social') well beyond the traditional workplace (the 'factory'), we need to both update and expand this mapping to account for more recent developments and to include further sites and practices unaccounted for or undercounted by the wage system: because what the Wages for Housework slogan called housework, namely household-based reproductive labour, is not the only form of social productivity not covered by the wage (a point with which Wages for Housework theorists were, incidentally, in full agreement). Let me list just a few of these forms of economic productivity across the expanded space of the social factory that the wage system fails to reward.

We can start with a fuller accounting of the productive inputs upon which capital accumulation is predicated. As James Boggs argued in 1963, "society must recognize that the magnificent productive tools of our day are the result of the accumulated labors of all of us and not the exclusive property of any group or class" (1963/2009, 47). Employers make use of social infrastructures produced through collective efforts over generations (Robeyns 2001, 84), commons used and abused in the course of their appropriation as 'natural resources', technologies developed by governments, and capital accumulated through slavery and both settler and international forms of colonialism. Wages compensate for none of these and taxes for precious little. The fear that there will be free riders who will receive a basic income is laughable given the truly massive levels of free riding on unremunerated labour, stolen property, public infrastructures, and privatised commons for which capital is given a free pass.

To continue this list of the wage-system's failures, consider the various modes of effortfulness that employers make use of but do not remunerate as part of the wage. This should include the educational efforts that develop a worker's general skills and aptitudes, as well as the time dedicated to developing communicative capacities, aesthetic embodiments, and even social networks that firms draw from but do not pay for. It should include as well the invisible 'housework' of setting up and maintaining the 'personal' digital devices that we also use for the job (Whiting and Symon 2020).Taking this more expansive measure of the reproductive labour necessary to produce labour power, we need to account for all the social, cultural, technological, and subjective infrastructures on which the more narrowly conceived structure of production - that is, work covered by the wage - depends. After all, why would it be legitimate, even from within the ideological logics of capital, for an employer to make profit from the skills and capacities that a worker had expended time and money to acquire? This is no small matter in the present moment when the employment system is being restructured around the ideal of the independently contracting entrepreneurial worker. This figure, as Lisa Adkins describes, is supposed to invest heavily, often through the accrual of household debt, in their own human capital and future employability $(2016,2)$. This would-be worker is, moreover, expected to assume all the risk and costs of landing a series of job contracts or subcontracts and often to cover what was once imagined as 
the employer's contributions to retirement accounts and healthcare costs. In this increasingly familiar scenario, Adkins notes that the distinctions among the employed, unemployed, and underemployed - with their once clearly differentiated relations to the wage - tend to break down as ever more of us move among these statuses more often and more quickly $(2016,2)$.

Furthermore, the list of what the wage system fails to account for should include the forms of scientific and creative production that companies draw on to make and market their goods. Why are all the materials that create and add value to goods and services not remunerated? This includes forms of scientific, communicative, technical, and social knowledges that make up part of the general intellect (see Virno 2004) as well as modes of artistic and popular cultural style and expression. In an economy that produces not just goods and services but along with them social landscapes, communicative contexts, and cultural forms, how do we adequately reward the labour that is exploited to create value? To put it another way, if in the post-Fordist social factory increasingly both productive and reproductive labour create not just commodities but affects and socialities, how are the inputs to these outputs to be measured and remunerated? The problem raised here is not only that the work is unwaged but the difficulty of remedying that mis-accounting by means of the same accounting practices that employers now use to measure their employees' contributions.

Here is yet another way that the wage system fails as a system of labour compensation. In a recent essay Andrew Ross catalogues the rapid expansion of unwaged or token-waged work up and down the employment hierarchy. Some of these are forms similar to those described above, whereby would-be employees seek to augment their employability through mounting household debts for student loans and other workready strategies, including non-paid or low-paid internships. It includes too, the sharing economy's expectation that we will monetise - in their language, 'share' - our own private assets like cars and housing. But the list also includes prison labour and various forms of unwaged digital labour used to create data and algorithms, as well as the oldfashioned wage theft that is often made easier through the proliferation of informal employment arrangements. "The social factory", Ross concludes, "is no longer an avant-garde thesis proposed by the first generation of autonomous thinkers back in the mid-70s. Today, we see it written all over the landscape of modern work" $(2017,197)$.

Lastly, we need to take a full accounting of the large, arguably enormous, numbers of people excluded or marginalised within the wage system because they do not conform to the model of the ideal waged worker. How many of us really possess the full list of capacities that will allow us to devote 40 hours to intensively focused effort over the course of a 5-day week, which is the standard for full-time work? What about those of us with cognitive, emotional, neurological, or physical differences that mean we cannot always, or sometimes ever, work in the ways or for the durations that are expected of this remarkably restricted archetype of the normative worker? For that matter, what about the times of life when even the otherwise affectively acceptable worker is taken over by joy or overcome by grief? How can we be expected to work a lifetime without more than - and this is of course the best-case scenario - a little vacation time and a few sick days? The family is supposed to be our safety net. But as Ailsa McKay and Jo Vanevery point out, whereas the state assumes the family is our first option, many of us see it only as a last resort $(2000,277)$. And, of course, this assumes that we have families, that they are bearable, and that these families include waged workers who have sharable income and also members who are willing and capable to perform the necessary caring labour. In other words, it means that too many of us have nothing or little in the way of support when our body-minds are rendered disabled by the standard 
forms of waged work. Sunny Taylor, noting the damaging effects of the fact that "many, though by no means all, disabled people will never be good workers in the capitalist sense", calls for the right not to work with pride: "the right not to have your value determined by your productivity as a worker, by your employability or salary" (2004, 39-40).

Before concluding this accounting project, I want to address very briefly a shortcoming of the work and family economy that was not part of the rationale for Wages for Housework but is often highlighted in defences of basic income, namely the problem of technological unemployment. The literature on the question of whether, or to what degree, robots and computers are replacing workers is extensive. Two claims are frequently cited. On one side, critics cite a report released by two Oxford University researchers that estimated that almost half of all jobs in the US are at risk of computerisation (Frey and Osborne 2013); on the other side economists often recite historical examples when mechanisation eliminated jobs in one sector only to open up employment in another, as when farmhands became industrial food workers, and assure us that this trend will continue in the digital age. Beyond raising a question about the quality of those new jobs they promise and expressing some doubt about whether those economists are really describing the timeless laws of motion of a capitalist economy or historical outcomes that were the product of decision-makers situated within specific social, political, and cultural conjunctures ${ }^{3}$ I will not address the issue of technological unemployment. Regardless of how many will be displaced by machines, it seems a less scandalous problem with the capitalist work and family system, that is to say, it seems a more legible, more properly technical problem with the system, around which there is more agreement about its meriting some kind of fix. Together with its potential impact on relatively privileged workers, this may help to account for the attention it has received in the popular media. Consider, by contrast, the long history of economic disenfranchisement and discriminatory labour markets that produce racialised employment disparities, as in a black unemployment rate in the US that is almost twice that of the rate of white unemployment. As the 1960s and 1970s US National Welfare Rights Organization argued, "as a wealth distribution system employment has never worked well for the poor, especially the black poor" (quoted in Sherwin and Piven 2019, 137). Annie Lowrey identifies a similar shell game: "all this talk about robots and technological unemployment and worlds without work distinguished UBI from welfare - a distinction that has muted a conversation about race and universal benefits that seems so salient, vital, obvious" $(2018,149)$. My point is that technological unemployment, to the extent that it is or will be a significant problem, is only the tip of the iceberg of the waged labour economy's irrationalities, exclusions, forms of marginalisation, and mis-accountings.

Let me conclude this part of my argument by applying two basic insights from the Wages for Housework campaign. The first is that in failing to account for reproductive labour, the wage obscures the true length of the working day (Cox and Federici 1976, 9). In the present context, a charge once levelled with a certain hyperbole is coming closer to something like a dry description: "every moment of our lives functions for the production and reproduction of capital" (Cox and Federici 1976, 9). Second, the wageand-family system excludes too many of us to function as a credible mechanism of income allocation. The already rather spectacular mis-accounting of productive activity

${ }^{3}$ Srnicek and Williams make a similar point about this one-dimensional reading of economic history: "sanguinity based on past experiences overlooks the political and contingent basis of this historical record: government policies, workers' movements, the gendered division of the labour force, and simultaneous reductions in the work week have all played a role in sustaining employment in the past" $(2016,88)$. 
they identified in the 1970s is arguably much more dramatic today and the exclusions enacted by the wage and family system possibly even more damning. Basic income, as a universal and unconditional social wage, offers a more rational and more equitable way to distribute income and reward forms of productivity. Moreover, the process of demanding that universal and unconditional income "provides a perspective from which the social nature of work, its invisible domestic aspect and its extension to every area of our lives become more readily apparent" (Srnicek and Williams 2016, 140).

\section{Lesson \#2: The Demand is Neither Reformist nor Revolutionary}

A number of current debates about the politics of basic income are obscured by the old dichotomy of reform or revolution. Either the demand is read - or rather misread as a bid to effect a revolutionary overthrow of capitalism, to which its critics respond that it would do no such thing since money, capital, and state would still exist (Dinerstein, Pitts and Taylor 2016); or it is dismissed as only a reformist ploy that would serve to consolidate the power of the capitalist class (Kleiner 2016). If these are the choices, either reform or revolution, there is no question - and I do not know of anyone who has ever denied this - that the demand for a basic income is a bid for reform. A demand for a universal, liveable, basic income is not a proposal to replace the capitalist wage system, but only to loosen its grip on us somewhat by providing income to those of us now shut out of or rendered precarious in relation to waged work and to those of us whose contributions to social (re)production are not now remunerated with wages. It would also give individuals a stronger position from which to negotiate more favourable employment contracts, some leverage to demand better jobs, and better enable them to make choices about what kinds of households and intimate relationships they might want to exit from or to form. While these are not, to put it mildly, insubstantial benefits, by no means do they add up to a revolutionary postwork or postcapitalist vision. On the contrary, I think a basic income guarantee is likely to be the only way capitalism will be able to sustain itself materially and ideologically in the near future as the wage system and family model continue to reveal themselves inadequate to the task of distributing income and organising productive and reproductive cooperation.

But that said, I do not accept the conceptual opposition of reform and revolution as a useful vocabulary of social change. The Wages for Housework theorists offer an instructive conception of their demand in terms that refuse the traditional either/or dualism: "Obviously as long as wages exist so does capital. To this extent we do not say that achieving a wage is the revolution", Cox and Federici admit. But that is not to say that it is not a "revolutionary strategy" (1976, 13-14). Federici explains it this way: "Wages for Housework, then, is a revolutionary demand not because by itself it destroys capital, but because it attacks capital and forces it to restructure social relations in terms more favourable to us" $(1995,191)$. Winning such a wage was not the final goal but only a step in its direction, and demanding that wage was not a simple claim but rather a complex practice. The demand for Wages for Housework was understood as first, a perspective, and second, as an organiser of power. First, as its advocates consistently argued, wages for housework is not just a demand, it is a "political perspective which opens a new ground of struggle" (Cox and Federici 1976, 3). As a perspective, it was not only a matter of the content of the demand, but of the critical analyses that inform the demand and that might be elicited in efforts to advocate for it. Second, the demand for Wages for Housework was described by proponents as a demand for power (Edmond and Fleming 1975, 126). By their estimation the demand for wages was a way to empower a collective struggle to win the resources that could enable them to make further demands. 
I see the demand for basic income in similar terms. Not only could it substantially improve people's lives, it could also provide material support for the time and effort necessary to fight for further reforms and, at the same time, pry open a conceptual space in which we might be able to think more critically about work and non-work and more imaginatively about how they might be further transformed. A demand is not just a goal but a process; as such, it must be explained, justified, argued for, and debated; the ambitions of the demands for Wages for Housework and basic income are not just policy-oriented but are also epistemological and ontological. That is, they are also opportunities for articulating a critical vocabulary through which we can interrogate the present, and for cultivating desires for new ways of living. By this more capacious measure of what a demand is and what it can do, we would judge the success or the failure of a movement for basic income not only in terms of whether the policy is implemented, but also in terms of the collective power, organisational forms, critical consciousness, and new demands that the process of demanding generates.

To pursue this on a different register, like Wages for Housework, the demand for basic income I am defending is not a technocratic fix but a political process advanced by social collectivities. There are two parts to this claim, one about the demand's relationship to a movement or movements and another about the demand's relationship to other demands. The demand for Wages for Housework, it is important to note, was not invented by its most prominent theorists; it circulated first as a feminist movement demand that was subsequently taken up more widely once it proved capable of generating both political action and theoretical debate (see Dalla Costa and James 1973, 5253, Note 16). The reform in and of itself would be nonsensical without the feminist movement that would be energised by the process of winning the immediate demand and continue the struggle for further demands after it was won. Similarly, simply achieving a basic income - perhaps, one might imagine, through the election of a political candidate, like Andrew Yang, who could somehow spearhead its adoption - is neither feasible nor desirable. I will further address this later in the argument, but a liveable minimal income will not be achieved with a single win; it will involve a protracted political battle that requires the continuing support of a powerful coalition of activist groups. Part of the process of demanding a basic income is building that coalition and cultivating that power rather than simply crunching the data and computing the numbers that would sell it as a cost-efficient and easily digested policy proposal. Second, basic income is not proposed here as a panacea or silver bullet; not only would it represent at best a step in the direction of an anticapitalist future rather than its attainment, it is also often advocated as one of a set of demands (see, for instance, Pateman 2003; Rogers 2017; Undercommons 2016). For example, a number of us defend the demand for basic income alongside the demand for shorter hours (Stronge 2017; Srnicek and Williams 2016; Weeks 2011) and others alongside reparations (Warren 2017) and new forms of worker organisation (Rolf and Watterson 2017).

\section{Lesson \#3: The Demand is Antiproductivist}

Wages for Housework's commitment to what some, using a kind of theoretical shorthand, refer to as the 'refusal of work' links the project to the autonomist Marxist tradition. That tradition of Marxist thought directs its critique of capitalism not only to exploited and alienated work but also to the overvaluation of work; it endorses not only the struggle for more and better work, but also the struggle for less work. In demanding wages, Wages for Housework activists were not seeking mere recognition for the moral value of their contributions; according to Cox and Federici, "it is only from the capitalist viewpoint that being productive is a moral virtue, not to say a moral imperative". They 
continue: "our power does not come from anyone's recognition of our place in the cycle of production, but from our capacity to struggle against it" $(1976,6)$. As the New York Wages for Housework Collective put it, "we do not ask for the 'right to work.' We do not want work, but want to be liberated from work" (Federici and Austin 2017, 34). Together with their antifamilialism, their antiproductivism was what set Wages for Housework apart from so many other currents of Left thinking and what so often raised the ire of their critics. "The left is horrified by the fact", Cox and Federici write, "that workers male and female, waged and unwaged - want more money, more time for themselves, more power" $(1976,18)$. The workerist Left that celebrates the dignity of work proposes merely palliatives for its alienated forms so that it will better deserve the pride of place they too assign it: "'job enrichment', 'workers' participation', 'workers' control', 'participatory democracy"', which is to say, "a bit more of the family in the factory (more individual concern, responsibility, identification with work)" (1976, 19-20). By affirming, even if rearranging, the existing values of work and family, they are "espousing longcherished capitalist utopias" $(1976,19)$.

This part of the legacy of Wages for Housework would seem to be even more relevant today. Because the ideology of work - that cultural overvaluation of work that sings the praises of hard work for long hours as an individual calling, moral obligation, and social duty; that prescribes waged work as the essential requirement for independence, primary path to self-development, and singular opportunity for self-expression; and that encourages us to organise our lives around and invest our identities in work - remains a crucial support system for an economy that accumulates great wealth for a few and lifetimes of poorly or non-paid and all-consuming waged and unwaged work for the rest of us. This orientation towards work is commanded by most employers who profit to one degree or another from their employee's enthusiasm for work and selfdisciplined commitment to the organisation's goals. This orientation is even more advantageous for those employers who want us to bring more of ourselves to the job, not only our manual and mental capacities, but our hearts and souls, or more specifically our social skills, affects, emotions, and creativity. This productivist ethic entails a project of subjectification indexed to the maximisation of one's employability and, perhaps as a supplement, marriageability. Where a strong work ethic is a key element of productivity, where it is part of the labour power that employers purchase and put to work, our willingness to call these values and modes of being into question is, I would argue, a necessary rather than optional dimension of political rebellion.

The antiproductivist potential of a basic income demand can be illustrated through a critique of the demand for full employment or a jobs guarantee that is sometimes offered as an alternative. The two demands differ in terms of which future is desirable and possible. From the perspective of this demand for basic income, full employment or a guaranteed job, if won, would be a nightmare: a massive expansion of make-work, including what James Boggs names "war-work" (1963/2009, 68), Arne Kalleberg calls "bad jobs" (2011), and David Graeber labels "bullshit jobs" (2018), delivering us all to the rarely hindered rule of employers in the private government of the workplace (Anderson 2017) such that "the category of laborer is not done away with, but extended to all" (Marx 1987, 100). A nightmare indeed, if it were not a pipedream animated by a Fordist nostalgia for a mythical past of full-time, secure, disciplined breadwinners or an imagined future in which full employment means something other than it does now, namely the partial employment prescribed by the political economists who insist on a margin of unemployment as necessary for a healthy economy. It reinforces rather than challenges "the capitalist organization of society that imposes work as the only condition of our being allowed to live" (Cox and Federici 1976, 12). 
My argument here is that the unemployed, unemployable, unwaged, precariously employed, overworked, and people who do not love their work may be suffering not primarily from the lack of a good job (whatever that might entail), but from a lack of income together with the dogma, widely disseminated and enforced throughout society, that work is liberating and that having a job is the only path to a worthy life. As an effort to loosen the grip of waged work on our lives, a basic income demand is also an opportunity to critically assess the necessity and meaningfulness of waged work, at what duration, under what conditions, and relative to other practices and pastimes.

\section{Lesson \#4: The Demand is Antifamily}

Wages for Housework's antifamialism is inseparable from its antiproductivism insofar as the institution of the family is part and parcel of a capitalist system of waged labour. Each enlists individuals into specific relations of production and reproduction, organises and divides those tasks, and serves as one of the two major mechanisms of income allocation. To accomplish those tasks the family recruits people into households, governs their labouring activity, scripts aspects of their gender, sexual, and generational relations, and mediates the meaning of their experience. The privatisation of the family is absolutely key to this. As Cox and Federici note, "it is the essence of capitalist ideology to glorify the family as a 'private world'" $(1976,9)$ because it serves to code the reproductive labour performed under its auspices as a private responsibility that merits neither remuneration nor support services. The privatisation of care is crucial to the economy of the family: the enormous amount of time, skill, and energy devoted to childcare, eldercare, the care of the ill, the care of the disabled, self-care, and community care, without which whatever you want to delimit as the economic system would not exist, is provided largely free of charge and disproportionally by women in the moments left outside of income-generating work.

But to argue that domestic labour was part of the valorisation process was not to imply that this work was something to celebrate or revere. Wages for Housework theorists wanted to make us understand that what they called housework was socially necessary labour that requires, for example, more time off waged work to accomplish, but not to overvalue it as such - to insist rather on its demystification, de-romanticisation, and de-privatisation together with its de-gendering. As work, it too is something to struggle against becoming the whole of life. This could mean agitating against, to name only a couple of things, the gender division of this work; the poor conditions of waged domestic work, which includes confronting the division of domestic labour by class, race, and nation; and forms of work intensification that have been disseminated through the ideology of intensive mothering. And it would require the invention of new ways of organising and sharing household work and of making it meaningful.

The potential antifamilialism of the politics of basic income, its critique of and support for possible alternatives to the privatised nuclear family as a political-economic institution and cultural norm, is a particularly urgent intervention. The heteropatriarchal family may function as a haven in a heartless world for some; for others it is a sad and dangerous site. A 2018 UN report, which found that more than half of female homicides around the world were committed by intimate partners or relatives, was released with a headline that I suspect surprised not a single feminist, naming the home as "the most dangerous place for women."

${ }^{4}$ https://www.unodc.org/unodc/en/press/releases/2018/November/home--the-most-dangerous-place-for-women--with-majority-of-female-homicide-victims-worldwide-killed-by-partners-or-family--unodc-study-says.html 
Sheila Rowbotham put it more eloquently in a text from the 1970s: "it is not surprising that violence breaks out in the family, or that people are made victims of families, that children are devoured, and smothered and hurt and battered in families. The family under capitalism carries an intolerable weight" $(1973,77)$. As Silvia Federici argued, family violence is not just a legal issue but an economic one: "If we are short of money we will always be vulnerable to domestic violence, or will be forced to choose between the violence in the home and the equal violence of the sweatshops" (Federici and Austin 2017,154$)$. Not only might a basic income, by better enabling individuals to decide whether to enter into a particular household division of domestic labour, empower us to negotiate better working conditions for that labour, it can also serve as a resource that could be used to exit a physically or otherwise abusive household relationship and to materially support the possibility of cultivating more sustaining and sustainable relationships of caring and sharing. ${ }^{5}$

\section{Lesson \#5: The Demand is Coalitional}

Whereas I call the demand for a basic income a coalitional demand, the proponents of the demand for Wages for Housework used the language of class politics to describe something comparable. Just as we had to revise our understanding of a capitalist mode of production to include the processes by which its workers are reproduced, the architects of the demand for Wages for Housework insisted that we also had to rethink who counts as part of the working class. Wages for Housework was understood as a movement by and for the wageless, because to be wageless, as they see it, is not to be outside the capitalist wage relation. Wages for Housework is "a political perspective for all those strata of the class whose powerlessness has up to now been absorbed within the family": their lists include the elderly, children, disabled people, the unemployed, students, welfare recipients, prisoners, and prostitutes (in Edmond and Fleming 1975, 19; Toupin 2018, 52).

Wages for Housework's call for the Left to support their demand for wages was understood as a bid for class unity. Capital's divisions of the working class along the lines of waged versus unwaged, employed versus unemployed, working versus retired, student versus worker, are confirmed as effective mechanisms of class pacification every time a narrow conception of the working class is defended by the Left. Drawing from the archive of working-class political history, we could certainly add further forms of conceptual exclusion to the lists offered in the Wages for Housework literature: proletariat versus lumpenproletariat, forced versus free labour, and formal versus informal work, as well as non-intersectional conceptions of class versus race, class versus gender, class versus disability, and class versus citizenship and nation. "Sexism, racism, and welfarism", for example, are not just the expression of individual moral failings; they are "ways of regulating and dividing the working class" (Cox and Federici 1976, 10).

${ }^{5}$ It is worth clarifying that the feminist critique of the institution of the family is not a critique of social relationships or shared households per se. Gourevitch and Stanczyk appear to conflate the two when they argue that, because they calculate that in order to live without waged work an individual would need to pool their income with others, feminist defences of basic income that draw on "claims about liberation from compulsory cohabitation and domestic relations of personal dependence" are mistaken. The two options they pose, either the lone individual or "compulsory cohabitation and domestic relations of personal dependence" $(2018,158)$ might well be read as a symptom of the continued hegemony of the ideology of the heteropatriarchal family. 
What I am calling a coalitional conception of the working class, as an identity of differences, must be made even broader with the demand for a basic income, extending to even more of us failed by the institutions of work and family. The list of those who might find cause in their own experiences to support the demand includes a myriad of precariously employed, unemployed, underemployed, non-waged, low-waged, and overworked workers. The demand has received support from activists involved in a number of social movements, including domestic worker organising (Poo 2017), civil rights (King 2010), welfare rights (Tillmon 1972), Black power (Black Panther Party 1966), sex worker rights (Cruz 2013), and the Movement for Black Lives (n.d.). To the extent that it could provide an alternative to the risks of underground economies and support for the formerly incarcerated, and in these respects potentially "deal a real blow" to mass incarceration (Shelby 2017, 46; Warren 2017, 58), it is also relevant to the politics of prison abolitionism. As an alternative to the environmentally unsustainable economics of job growth, the demand for basic income could be a focal point for red-green coalition politics (Srnicek and Williams 2016, 160-161). ${ }^{6}$ To illustrate her argument that a basic income could appeal to a broad constituency, Juliana Bidadanure offers a nicely suggestive partial list: "domestic workers, truck drivers, stay-at-home moms, abused dependent partners, ex-cons, sex workers, starving artists, people who hate their jobs, people who love their jobs but need to reduce hours, volunteers, interns, students, poor pensioners, precarious workers, people who want to start an ecovillage, and so many more" $(2017,55)$. Thus, while I agree with Gourevitch and Stanczyk that a basic income "will come only when there is a working class constituency that is organized and powerful enough to be able to extract it" (2018), like the proponents of Wages for Housework, I would argue in favour of a broader conception of who might count as a member of the working class constituency and what counts as organised labour politics.

This coalitional conception of the demand for a basic income contradicts or reveals the weaknesses in two critiques of the demand: one that describes it as incompatible with traditional forms of labour organising and working class politics (Gourevitch 2016; Gourevitch and Stanczyk 2018), and a second that accuses its supporters of fraternising with the enemy. The first critique, that the basic income demand is somehow at odds with the politics of organised labour, presumably centred around unions, seems misplaced. ${ }^{7}$ Rather than a zero-sum game that requires party unity around a particular program of action, I see no reason why the relationship between the politics of a basic income demand and union politics would be a matter of either/or rather than both/and. Even a cursory tour through the basic income literature reveals wide support for unioncentred and other more traditional forms of workplace politics and regulation (for just a few examples, see Rogers 2017; Van Parijs 2017; Rolf and Watterson 2017). Moreover, traditional union-based politics, with its continued tendency to focus on some employment sectors over others, waged workers more than unemployed workers, and

${ }^{6}$ The relevance of this basic income demand to movements mobilised around climate change and environmental collapse is an important topic that, because I confine my discussion to major lessons gleaned from Wages for Housework, I did not elaborate upon.

7 "The illusion is that the legislative introduction of a generous universal basic income program can replace traditional forms of labor organizing, or else that its legislative introduction should be prioritized as an essential stepping stone to more effective labor politics. This attitude is held by all those who spend time studying, piloting, or simply entertaining generous basic income proposals in their writings, while showing much less interest in the timeworn tactical question of how to organize a durable majority of the working classes" (Gourevitch and Stanczyk 2018, 151 [emphasis added]). 
waged rather than unwaged workers means that it is a necessary but certainly insufficient approach to the struggle over work.

The second critique of the kind of basic income demand I advance here, which I find wholly specious, is the accusation of strange bedfellows, that advocating the demand renders one complicit with the enemy. ${ }^{8}$ Although 'bedfellow' is a decidedly inapt metaphor for the realities of coalitional politics, its evocation of nonnormative, 'promiscuous' sexual conduct certainly succeeds in conveying the specific flavour of moral outrage that the critique seeks to marshal and its authors to enjoy. Since I do not want to linger on my response to a charge that I find without merit, this will have to suffice: there are plenty of ways to lose the struggle for a basic income while preserving one's righteous purity; but there is no way to win it without the political work of building majorities that can disseminate new conceptual vocabularies and topics of analysis, generate public discussion and debate, elect politicians, push through legislation, pursue juridical avenues when necessary, and compel businesses and corporations into support for the policy. There is something profoundly apolitical about the critique of working with the enemy. Politics as I understand it is about critiques and visions, strategies and tactics, and gaining and losing ground in protracted struggles. As a collective practice aimed at changing some of the rules of the game, a vanguard, class fraction, separatist group, or any other restricted, if ideologically untainted, agent of change will not be up to the task.

The Black feminist theorist and activist Bernice Johnson Reagon offers a distinction that I find helpful in trying to explain my exasperation with this line of criticism. In the text from a famous speech from the early 1980s Reagon insists on a difference between what she calls a home and a coalition. Although she was using the terms to make an intervention into the dilemmas of intersectional feminist identity politics, I think they can be applied more broadly. Home, Reagon explains, is where you meet with people who share your experiences, perspectives, or analyses; it is a safe, comforting and, to be sure, quite often an intellectually generative space inhabited by the likeminded. Coalition, on the other hand, takes place in the streets and is, as she describes it, some of the most dangerous work you can do. The problem, Reagon observes, is that "some people will come to a coalition and they rate the success of the coalition on whether or not they feel good when they get there. They're not looking for a coalition; they're looking for a home!" While we arguably need both homes and coalitions, safe spaces and political projects, it is critical, Reagon argues, that we recognise that they are not the same thing $(1983,346)$.

As a way to apply Reagon's conceptual division between home and coalition to my reading of the 'strange bedfellows' critique, I want to graft it onto to a different distinction, that between ethics and politics. Ethics, to work with Reagon's analytic, can be practiced individually at home, that is to say, in spaces wherein you can enjoy the company of compatible people with whom you can share a more seamless ideological existence - certainly something that everyone could use at some time. Politics, in contrast, is a collective endeavour that takes place in the public spaces of the streets. To engage in politics, and particularly, to win a large-scale reform, requires confronting the complexity of the broader political landscape and coalescing with those with whom you disagree. Politics, to make a point that I will go on to develop later, is an essentially risky endeavour.

${ }^{8}$ Since this critique is at least implicit in quite a bit of the critical literature on the basic income demand that I have read, I do not cite particular texts. 


\section{Lesson \#6: The Demand is Feminist}

For some of its critics, the basic income demand is not a properly, or at least not a compelling, feminist demand, either because it does not single out unwaged domestic work in a way that will contest the devaluation of that work, or because it would only end up reinforcing the gender division of domestic labour if more heterosexual women with children or other care recipients opt out of or reduce their waged work while more heterosexual men do not (see, for example, Gheaus 2008). While I think both of these are important points of discussion and debate, and as much as I would like to imagine ways to collectively rather than only individually challenge the gender division of domestic labour, there are two further reasons - in addition to my earlier argument about the many forms of capitalist mis-accounting besides domestic reproductive labour why these critiques do not dissuade me from my support.

The first of these is that naming gendered phenomena always risks validating popular beliefs about their naturalisation, a conundrum with which feminists have long had to contend. The lesson I draw from Wages for Housework on this point is largely a cautionary tale. Proponents of the demand, like Federici, remind us that it was cast as wages for housework not for housewives $(2012,9),{ }^{9}$ but there was some slippage between these two terms within the campaign and, regardless of the precise slogan, many listeners equated them so that the longstanding association of domestic labour with womanhood was often confirmed rather than challenged by the discourse. Although the basic income demand does not directly contest the invisibility and gendering of domestic reproductive labour in the way that the slogan of Wages for Housework once could, neither does it invoke the potentially reified vocabularies of a Fordist gender regime. In that sense I would argue that the gender neutrality of the demand for basic income is not necessarily a liability, especially if arguments for the demand include a strong feminist voice.

As for whether a basic income would function to perpetuate the traditional gender division of labour in the heteropatriarchal family, compelling arguments have been made on both sides of the debate. I tend to agree with those who predict that a basic income would provide more opportunities for both men and women to combine waged work and unwaged caring labour (Pateman 2003, 140). But that said, I would support basic income as a feminist project even if it were to end up providing material support for the traditional division of labour in the heteropatriarchal family. The feminist politics that I support, which is of course just one of myriad competing versions, approaches feminism as a revolutionary project to transform the intersecting hierarches of heteropatriarchal racial capitalism, not just the relative positions of men and women within it. ${ }^{10}$ Consequently, the future of the domestic gender division of labour is not my only metric of feminist judgement.

${ }^{9}$ It should be noted that when Wages for Housework writers did use the term housewife, they typically defined it in very broad terms to include any woman who is expected to perform domestic labour, regardless of whether or not they are married, have children, or work for wages (see, for example, Dalla Costa and James 1973, 19).

10 There is a more complicated argument that I will not pursue here about how the feminism of the demand for Wages for Housework, as well as of the demand for basic income that is developed on its model, is embedded in the methodologies of both demands. Each prioritises social reproductive labour both as integral to a capitalist economy and as the point of entry into their critical analyses and political proposals. 


\section{Lesson \#7: It is a Demand for Autonomy}

Some critics of the basic income demand prefer as an alternative something on the order of a demand for universal basic social services, like education, housing, healthcare, childcare, and eldercare. ${ }^{11}$ Interestingly, proponents of Wages for Housework were faced with the same critique launched by those who sought not wages for housework but the socialisation of it through state-supported services. Wages for Housework advocates claimed that they wanted services as well, which they sometimes coded as another part of the social wage that the state should pay to create "better working conditions" for housework (Federici 1995, 192), ${ }^{12}$ but they were primarily committed to the demand for wages and were at best sceptical about state-provided services. Although I do not share their deep suspicion of social services, which they often cast as further outposts of either state socialist or capitalist rationalisation and regimentation (Cox and Federici 1976, 19-20), Cox and Federici's attack on the ersatz reforms that amount to a "bit more of the factory in the family" that enable more productivity and efficiency of housework, which they coupled with the "bit more of the family in the factory" designed to heighten our personal investments in waged work cited earlier $(1976,19)$, turns out to be more relevant to the present moment wherein the only solution on offer for the double day is not the socialisation of housework but its commodification, with a market that provides household services for the class-advantaged few and low-waged jobs for others. While I would argue that the basic income demand should be coupled with demands for a variety of publicly provisioned social reproduction support services, I also think that the defence of the demand for Wages for Housework in the name of autonomy offers further insight into the advantages of coupling those demands with the demand for a basic income.

The concept of autonomy in Wages for Housework and the autonomous Marxist tradition with which it is associated is multivalent. For example, when Selma James declared that "this is our demand for autonomy," she refers both to a political distinction from other left organisations and to a measure of relief from the "capitalist organization of our lives" $(1976,26)$. This concept of autonomy is indexed not to an ideal of individual self-sovereignty but rather to an ideal of collective self-government or collective projects of self-constitution; wages, theorists like James thought, could provide some of the material support to enable some measure of independence from what corporate HR-speak calls the struggle for "work/family balance" and Marxist feminism calls the twin institutional pillars of heteropatriarchal capitalism. Similarly, a basic income, to the extent that it could enable some to opt out or negotiate better conditions of waged work and family membership, could provide, certainly nothing so ambitious as freedom from, but rather a measure of protection from or leverage against both the vast powers of employers and the weight of family roles and expectations.

In another register the demand for autonomy can also be understood as a bid to break from the paternalism that has been part and parcel of the US welfare state. Welfare rights activism, as another movement by the wageless, and particularly the 1960s and 1970s National Welfare Rights Organization in the US, had a profound impact on Wages for Housework. In a text from 1975 Federici describes them as "the spearhead of the feminist movement" and explains why: "The struggles of welfare mothers in the

${ }^{11}$ For a radical version of the demand for services as an alternative to basic income, see Bastani $(2019,213 ; 226)$.

12 To note one specific example, the New York Wages for Housework Committee engaged in struggles over decent housing, casting it as a matter of workplace conditions (Federici and Austin 2017, 63-69). 
1960s marked a radical break with the socialist tradition that is centred on the ideology of work and productivity" (Federici and Austin 2017, 101; 104). The NWRO advocated for many reforms to the conception and administration of social welfare and defended a basic income as an alternative to miserly and demeaning means-tested programs that create profoundly troubling distinctions between the worthy and unworthy poor, the able-bodied and their others. As Jenny Brown notes, means-tested programs are a way to divide people: "the vast majority of struggling people who don't qualify against the even more struggling group of people who do" $(2019,150)$. The NWRO also fought back against attempts to control their consumption through vouchers and other limitations on their spending. As a text produced from an alliance between Wages for Housework and welfare activism from the 1970s explained, with a sharp - and loud - rebuke to the paternalism of the welfare system, "we all WANT LESS WORK, MORE MONEY AND MORE TIME FOR OURSELVES TO DECIDE WHAT WE WANT TO DO WITH OUR LIVES" (Federici and Austin 2017, 109). As much as I support the expansion of social services, the additional merit of a universal, unconditional social wage or basic income is its antipaternalistic insistence that its recipients retain control over its use.

Wages for Housework advocates also allied with both abortion rights and anti-sterilisation activists to demand more autonomy in the form of meaningful control over childbearing and rearing. They demanded wages so that they could, among other things, "decide if, when and under what conditions to have children" (Federici and Austin 2017, 45). Deciding not to have children because one does not have the money or time to raise them does not count as reproductive choice: "As long as we have no money of our own because we work for nothing at home and for crumbs outside the home, none of us can choose whether or not to have children, and all of us face sterilization even if our tubes are not cut" (2017, 59 [case altered]). Furthermore, deciding either to have or not to have children in a situation of dependence within an isolated heteropatriarchal family is not a real choice $(2017,59)$. A basic income, like wages for housework, cannot in itself create the conditions for truly meaningful choices about whether to raise children or not. The addition of publicly funded high-waged, high-quality childcare services would, for example, bring us at least a step closer to the realisation of those conditions. But services alone, absent the basic income that could also enable a measure of choice about the terms of one's participation with waged work and family, would not. Proposals from the Left to demand services or unionisation instead of, rather than alongside, a basic income, whether in the name of decommodification or collective solidarity, should recognise the risk of the paternalism that may be enabled when the power of social engineering is prioritised over delivering income to those most in need.

\section{Lesson \#8: The Demand is National, International, and Potentially Transna- tional}

Wages for Housework was conceived and to some extent practiced as an international movement. Networks of international and national groups organised conferences and circulated newsletters and other texts. But with precious little in the way of resources, cross-border communication in the 1970s was very difficult to sustain (Toupin 2018, 100). Today the basic income demand circulates through national and transnational networks with comparative ease. And although it is sometimes depicted as an extravagance of the wealthy nations, the basic income demand is being actively advanced in a variety of sites in the global system, where it is not necessarily GDP but also, as the South African case in particular illustrates, high levels of structural unemployment 
that can raise the profile of the demand and render it more legible as a viable possibility.

But the practice of levelling demands is also a local affair, dependent on the particularities of political, social, and economic contexts. This raises the issue of whether instituting a basic income in one nation like the US will trigger even higher levels of anti-immigrant sentiment and xenophobic political initiatives. This is an urgent problem to consider, although it is not exclusive to this particular national benefit. It is another reason why I think the formulation of basic income that some defend, as a citizen's income (see for example Robeyns 2001) or a stakeholder grant that could enliven a sense of national belonging (Ackerman and Alstott 1999, 44), is ill-advised. Instead, in order to emphasise the demand's transnational potential beyond the confines of the nation, it is better conceived as a social wage that is remitted to residents, not citizens. As with federal wage and hours law, it would be applicable to those with and without formal citizenship status. James Ferguson characterises this in terms of a politics of presence grounded in a less fixed and more capacious figuration of membership determined by "a concrete and embodied presence and the obligation it implies" (2015, 215). While this may be to "invoke a politics yet to be invented", as Ferguson notes, that is not to say it is not technically feasible, since "providing services to residents is often more practical than trying to sort out who 'belongs' where" $(2015,216 ; 213)$.

\section{Lesson \#9: The Demand is a Risk}

To recap the main features of the demand for basic income that I have attempted to defend against a variety of critiques, it is meant to ameliorate some of the failures of the wage and family system rather than replace the social welfare system; it is a wage not an entitlement program; it opens a critical perspective rather than simply naming a policy proposal; it is a political demand not a technical fix; it is part of a set of demands rather than a single magic bullet; and it is remitted to individuals not families and to residents not citizens. I have argued that basic income better addresses the profound problems with the work-and-family system than a jobs guarantee and that state-provided services are an important supplement to a basic income, but not a viable substitute for it. But although there is no shortage of red herrings strewn about the field of debate, there are also substantive intellectual differences that divide those who defend basic income from many of the demand's critics. One of the most significant of these turns on the approach to work in general and waged work in particular. On one side, the ideology of work that elevates work over other practices and imagines that even the forms of waged work that we are now offered are personally redeeming and an ethical duty is identified as a crucial support system for the capitalist work and family system; as such, is understood as precisely what requires interrogation. On another side, the antiproductivist potential of the demand to raise questions about and provide an alternative to the current place of work in our lives is anathema to those who believe that work is a human requirement and that it is fundamental to individual dignity and community cohesiveness.

This brings me to my final argument. I have also tried along the way to offer brief refutations of a few of the negative assessments of the basic income demand that I do not find either credible or convincing. Now I will turn to what I see as the most compelling critique, the challenge to the demand that I think should give everyone pause and that may well dissuade some from their support.

To explain it we need to recognise that in there are at least two major genealogies of the basic income demand in the US. My case for the demand draws from a Marxist feminist lineage that includes Wages for Housework, autonomist Marxism, the National 
Welfare Rights Organization, Martin Luther King, and the Black Panther Party among others. But there is a right-wing version - some refer to it as a neoliberal version - that draws on a different archive, including texts by Milton Friedman and Charles Murray. This right-wing version proposes the income as an excuse to shrink government by dismantling as many welfare, health, and antipoverty assistance programs as possible. The Undercommons, a political group from Los Angeles, usefully names the two models $\mathrm{UBI}+$, which they support because it adds basic income to other labour regulations and social programs, and UBI-, which advances basic income as a replacement for these initiatives (2016).

The problem is not that these very different demands will be confused; it is clear enough how these two approaches differ in myriad ways. The problem is tactical; the danger is that if it is to be won, basic income is likely to be instituted in stages rather than all at once. In fact there are two related perils: that it might be granted but at first only at the expense of too many assistance programs, and that it might be granted but initially at such a low level that it would, rather than empower workers to refuse the worst employment contracts and expand the non-work time in which to engage in political activism, serve to subsidise low-wage employers by offering their workers only a small supplement. The first of these seems more of a potential problem in those countries with more robust welfare states than the US. But in light of that first threat, it is important to argue for the income as a wage, not an entitlement, handout, or substitute for anything but minimally liveable waged employment.

The second problem, the likelihood of an initial low wage, seems more intractable and the danger of winning something less than a minimal liveable income is, to my mind, the most potentially devastating critique of the basic income demand. It means that what form the basic income program takes will depend on the power and endurance of the political forces behind its advocacy. As the supporters of Wages for Housework understood very well, the practice of political claims-making is always a risky endeavour. Here is how Dalla Costa once described what a demand is:

It is a goal which is not only a thing but, like capital at any moment, essentially a stage of antagonism of a social relation. Whether the [...] wages we win will be a victory or a defeat depends on the force of our struggle. On that force depends whether the goal is an occasion for capital to more rationally command our labor or an occasion for us to weaken their hold on that command. What form the goal takes when we achieve it [...] emerges and is in fact created in the struggle, and registers the degree of power that we reached in that struggle (Dalla Costa and James 1973, 53; Footnote 17).

To recognise a goal as a stage suggests a reconceptualisation of the political practice of demanding a basic income that places it within a longer temporality. Despite its appearance as a punctual event, as a win or a loss, the politics of a basic income will involve a longer process of winning it on our terms, as an unconditional, universal, liveable wage. Whether this 'foot in the door' incremental approach to political change is worth the risk is an important question, perhaps the critical question. Here we might recall the US first-wave feminist struggles about whether to support passage of the 15th amendment and wait for the 19th, or consider what it meant to support the 1938 Fair Labor Standards Act with its racist and sexist exclusions, some of which were later amended but only after many years and much effort (see Warren 2017, 57), or think about whether the Affordable Care Act will or will not serve as a step towards Medicare For All. The foot in the door can serve as a wedge to help pry it open further, or it can 
get broken. The ultimate reason why I think the basic income demand is worth this considerable risk is that our situation is dire: even before the COVID crisis, countless millions in the US struggled and often failed to meet even their most basic needs; I do not see how either more jobs or more services either alone or together are adequate to this emergency. That said, the only thing of which I feel truly certain is at the heart of another insight from Wages for Housework: "Feminism must start from what women need, not from what it might be easier to gain" (Federici and Austin 2017, 104).

\section{References}

Ackerman, Bruce and Anne Alstott. 1999. The Stakeholder Society. New Haven: Yale University Press.

Adkins, Lisa. 2016. Contingent Labour and the Rewriting of the Sexual Contract. In The PostFordist Sexual Contract: Working and Living in Contingency, edited by Lisa Adkins and Maryann Dever, 101-128. Palgrave Macmillan.

Anderson, Elizabeth. 2017. Private Government: How Employers Rule Our Lives (and Why We Don't Talk about it). Princeton: Princeton University Press.

Bastani, Aaron. 2019. Fully Automated Luxury Communism: A Manifesto. New York: Verso.

Bidadanure, Juliana. 2017. Basic Income Convergence. In Work, Inequality, Basic Income, edited by Joshua Cohen, 51-55. Boston: Boston Review.

Black Panther Party. 1966. Ten-Point Program. Accessed July 13, 2020. https://www.marxists.org/history/usa/workers/black-panthers/1966/10/15.htm

Boggs, James. 1963/2009. The American Revolution: Pages from a Negro Worker's Notebook, New Edition. New York: Monthly Review Press.

Brown, Jenny. 2019. Birth Strike: The Hidden Fight Over Women's Work. Oakland, CA: PM Press.

Cox, Nicole and Silvia Federici. 1976. Counter-Planning from the Kitchen: Wages for Housework, A Perspective on Capital and the Left. Brooklyn: New York Wages for Housework Committee.

Cruz, Katie. 2013. Unmanageable Work, (Un)liveable Lives: The UK Sex Industry, Labour Rights and the Welfare State. Social \& Legal Studies 22 (4): 465-488.

Dalla Costa, Mariarosa and Selma James. 1973. The Power of Women and the Subversion of the Community. Bristol: Falling Wall Press.

Dinerstein, Ana, Frederick H. Pitts and Graham Taylor. 2016. A Post-Work Economy of Robots and Machines is a Bad Utopia for The Left. The Conversation, May 23.

Edmond, Wendy and Suzie Fleming, eds. 1975. All Work and No Pay: Women, Housework, and the Wages Due. Bristol: Falling Wall Press.

Federici, Silvia and Arlen Austin, eds. 2017. Wages for Housework, The New York Committee 1972-1977: History, Theory, Documents. New York: Autonomedia.

Federici, Silvia. 2012. Revolution at Point Zero: Housework, Reproduction, and Feminist Struggle. Oakland, CA: PM Press.

Federici, Silvia. 1995. Wages Against Housework. In The Politics of Housework, New Edition, edited by Ellen Malos, 187-194. Cheltenham: New Clarion Press.

Ferguson, James. 2015. Give a Man a Fish: Reflections on the New Politics of Distribution. Durham: Duke University Press.

Frase, Peter. 2018. On the Politics of Basic Income. Accessed July 13, 2020. http://www.peterfrase.com/2018/07/on-the-politics-of-basic-income/

Frey, Carl Benedikt and Michael A. Osborne. 2013. The Future of Employment: How Susceptible Are Jobs to Computerisation? Accessed July 13, 2020. https://www.oxfordmartin.ox.ac.uk/downloads/academic/The Future of Employment.pdf

Gheaus, Anca. 2008. Basic Income, Gender Justice and the Costs of Gender-Symmetrical Lifestyles. Basic Income Studies 3 (3): 1-8. 
Gourevitch, Alex. 2016. The Limits of a Basic Income: Means and Ends of Workplace Democracy. Basic Income Studies 11 (1): 17-28.

Gourevitch, Alex and Lucas Stanczk. 2018. The Basic Income Illusion. Catalyst 1 (4): 151177.

Graeber, David. 2018. Bullshit Jobs: A Theory. New York: Simon \& Schuster.

James, Selma. 1976. Women, The Unions and Work, Or, What is Not to Be Done and the Perspective of Winning. London: Falling Wall Press.

Kalleberg, Arne. 2011. Good Jobs, Bad Jobs: The Rise of Polarized and Precarious Employment Systems in the United States, 1970s to 2000s. New York: Russell Sage.

King, Martin Luther. 2010. Where Do We Go From Here: Chaos or Community? Boston: Beacon Press.

Kleiner, Dmytri. 2016. Universal Basic Income is a Neoliberal Plot to Make You Poorer. openDemocracy, 25 November.

Lowrey, Annie. 2018. Give People Money: How A Universal Basic Income Would End Poverty, Revolutionize Work, and Remake the World. New York: Crown Books.

Marx, Karl. 1987. Economic and Philosophic Manuscripts of 1844. Trans. Martin Milligan. Buffalo: Prometheus Books.

McKay, Ailsa and Jo Vanevery. 2000. Gender, Family, and Income Maintenance: A Feminist Case for Citizens Basic Income. Social Politics 7 (2): 266-284.

Movement for Black Lives. n.d. Platform [website]. Accessed July 21, 2020. https://m4bl.org/policy-platforms/reparations/

Pateman, Carole. 2003. Freedom and Democratization: Why Basic Income is to be Preferred to Basic Capital. In The Ethics of Stakeholding, edited by Keith Dowding, Jurgen De Wispelaere, and Stuart White, 130-148. London: Palgrave MacMillan.

Pitts, Frederick and Ana Dinerstein. 2017. Postcapitalism, Basic Income, and the End of Work: A Critique and Alternative. Bath Papers in International Development and Wellbeing, Centre of Development Studies, University of Bath 55.

Poo, Ai-Jen. 2017. What a Basic Income Would Mean to Domestic Workers. Economic Security Project. Accessed July 21, 2020. https://medium.com/economicsecproj/what-abasic-income-would-mean-to-domestic-workers-69c30d6abbd2

Reagon, Bernice Johnson. 1983. Coalition Politics: Turning the Century. In Home Girls: $A$ Black Feminist Anthology, edited by Barbara Smith, 343-355. New Brunswick: Rutgers University Press.

Robeyns, Ingrid. 2001. An Income of One's Own: A Radical Vision of Welfare Policies in Europe and Beyond. Gender \& Development 9 (1): 82-89.

Rogers, Brishen. 2017. The Limits of Basic Income. In Work, Inequality, Basic Income, edited by Joshua Cohen, 87-92. Boston: Boston Review.

Rolf, David and Corrie Watterson. 2017. A New Social Contract. In Work, Inequality, Basic Income, edited by Joshua Cohen, 81-86. Boston: Boston Review.

Ross, Andrew. 2017. Working for Nothing: The Latest High Growth Sector? In Mapping Precariousness, Labour Insecurity and Uncertain Livelihoods: Subjectivities and Resistance, edited by Emiliana Romano, Arianna Bove and Annalisa Murgia, 189-198. London: Taylor and Francis.

Rowbotham, Sheila. 1973. Woman's Consciousness, Man's World. Harmondsworth: Penguin Books.

Shelby, Tommie. 2017. A Blow to Ghettoization. In Work, Inequality, Basic Income, edited by Joshua Cohen, 41-46. Boston: Boston Review.

Sherwin, Wilson and Frances Fox Piven. 2019. The Radical Feminist Legacy of the National Welfare Rights Organization. WSQ: Women's Studies Quarterly 47 (3 \& 4): 125-153.

Srnicek, Nick and Alex Williams. 2016. Inventing the Future: Postcapitalism and a World Without Work, Updated Edition. London: Verso. 
Stronge, Will. 2017. Misconstruing Post-Work. Autonomy [blog]. Accessed July 21, 2020. https://autonomy.work/portfolio/comments-recent-ubi-post-work-interventions-co-founderwill-stronge/

Taylor, Sunny. 2004. The Right Not to Work: Power and Disability. Monthly Review 55 (10): 30-44.

Tillmon, Johnnie. 1972. Welfare is a Women's Issue. Ms. Spring: 111-116.

Toupin, Louise. 2018. Wages for Housework: A History of an International Feminist Movement, 1972-1977. Translated by Kathe Roth. Vancouver: UBC Press.

The Undercommons. 2016. No Racial Justice Without Basic Income. Boston Review. Accessed July 13, 2020. http://bostonreview.net/class-inequality-race/undercommons-noracial-justice-without-basic-income

Van Parijs, Philippe. 2017. Real Freedom. In Work, Inequality, Basic Income, edited by Joshua Cohen, 66-71. Boston: Boston Review.

Virno, Paolo. 2004. A Grammar of the Multitude. Translated by Isabella Bertoletti, James Cascaito, and Andrea Casson. Los Angeles: Semiotext(e).

Warren, Dorian. 2017. Reparations and Basic Income. In Work, Inequality, Basic Income, edited by Joshua Cohen, 56-60. Boston: Boston Review.

Weeks, Kathi. 2011. The Problem with Work: Feminism, Marxism, Antiwork Politics and Postwork Imaginaries. Durham: Duke University Press.

Weeks, Kathi and Katie Cruz. 2016. Feminism, Marxism and the Cultural Overvaluation of Work. Canadian Dimension 50 (3).

Weeks, Kathi and Cameron Thibos. 2019. Feminist Politics and a Case for Basic Income. openDemocracy, 18 September.

Whiting, Rebecca and Gillian Symon. 2020. Digi-Housekeeping: The Invisible Work of Flexibility. Work, Employment and Society. https://doi.org/10.1177/0950017020916192

\footnotetext{
About the Author

Kathi Weeks

Kathi Weeks is a Professor of Gender, Sexuality, and Feminist Studies at Duke University. She is the author of Constituting Feminist Subjects (Verso edition 2018) and The Problem with Work: Feminism, Marxism, Antiwork Politics and Postwork Imaginaries (Duke University Press 2011).
} 